\title{
Further dispersion of the invasive alien species Corbicula fluminea (O. F. Müller, 1774) in the Oder River
}

\author{
Klaudia D. Cebulska ${ }^{*}$ and Mariola Krodkiewska \\ Department of Hydrobiology, Faculty of Biology and Environmental Protection, University of Silesia in Katowice, Bankowa 9, 40-007 \\ Katowice, Poland
}

\begin{abstract}
Corbicula fluminea is recognised as being one of the worst alien species in Europe and one of the world's most widespread non-indigenous species in freshwater ecosystems. In Poland, it was detected in a heated water channel of the Lower Oder Power Station near Szczecin for the first time in 2003. In the following years, it continued its spread in the Oder River and the Vistula River. Our study uncovered new findings of $C$. fluminea in the Upper Oder River, which are its southernmost localities in the Oder River. Its record in the Gliwice Canal indicates that this may be a new dispersion route to the east for this species.
\end{abstract}

\begin{abstract}
Keywords: non-native species / Corbicula fluminea / Oder River
Résumé - Poursuite de la dispersion de l'espèce exotique envahissante Corbicula fluminea (O. F. Müller, 1774) dans l'Oder. Corbicula fluminea est reconnue comme étant l'une des pires espèces exotiques en Europe et l'une des espèces non indigènes les plus répandues dans les écosystèmes d'eau douce. En Pologne, elle a été détectée pour la première fois en 2003 dans un canal d'eau réchauffée de la centrale électrique de Lower Oder près de Szczecin. Dans les années qui ont suivi, elle a poursuivi sa propagation dans l'Oder et la Vistule. Notre étude a permis de découvrir de nouvelles observations de $C$. fluminea dans le cours supérieur de l'Oder, qui sont ses localités les plus au sud dans l'Oder. Son signalement dans le canal de Gliwice indique qu'il pourrait s'agir d'une nouvelle voie de dispersion vers l'est pour cette espèce.
\end{abstract}

Mots clés : espèce non indigène / Corbicula fluminea / rivière Oder

The Oder River is the sixth largest river in Europe. Its estuary is considered to be one of the most exposed environments for the introduction of alien species in the Baltic Sea catchment. As the main harbour, it plays an important role in both marine and inland shipping and is regarded as a significant gateway for the dispersal of nonindigenous species (Gruszka, 1999; Bij de Vaate et al., 2002; Galil et al., 2008; Gruszka and Woźniczka, 2008; Leuven et al., 2009; Gruszka et al., 2013; Pabis et al., 2017). The number of alien macroinvertebrate species in the Oder River is still growing. By the 20th century, 16 non-indigenous species had been identified in the Oder estuary, among them were three mollusc species (Potamopyrgus antipodarum, Dreissena polymorpha and Mya arenaria) (Gruszka, 1999). Since then, 13 new alien species have been recorded in the lower and the middle courses of the Oder River including seven mollusc species-Lithoglyphus naticoides (Bij de Vaate et al., 2002; Piechocki and Szlauer-Łukaszewska, 2013), Ferrissia fragilis, Menetus dilatatus, Physa acuta (Piechocki and Szlauer-

\footnotetext{
*Corresponding author: kcebulska@us.edu.pl
}

Łukaszewska, 2013), Corbicula fluminalis (Łabęcka et al., 2005; Piechocki and Szlauer-Łukaszewska, 2013), Corbicula fluminea (Domagała et al., 2004) and Dreissena rostriformis bugensis (Woźniczka et al., 2016).

Mollusca are one of the most invasive animals in freshwater ecosystems and can pose a serious threat to native species (Francis and Chadwick, 2012; Lorencová et al., 2015). The Asian clam Corbicula fluminea (O. F. Müller, 1774) is a great example of this. The sexual populations of this species are restricted to the native Asian areas, but the androgenetic lineages are widely distributed in America and Europe (Pigneur et al., 2014). C. fluminea is recognized as one of the worst alien species in Europe (Nentwig et al., 2018) and one of the world's most widespread non-indigenous species in freshwater ecosystems (Hakenkamp and Palmer, 1999).

Many molluscs have proven to be very successful invaders. C. Aluminea is one of the species that is greatly extending its distribution range. In less than 100 years, it has invaded all of the continents, except Antarctica (Crespo et al., 2015). Since 2003, it has been spreading in the Oder and the Vistula Rivers; therefore, it is probable that it may also inhabit 


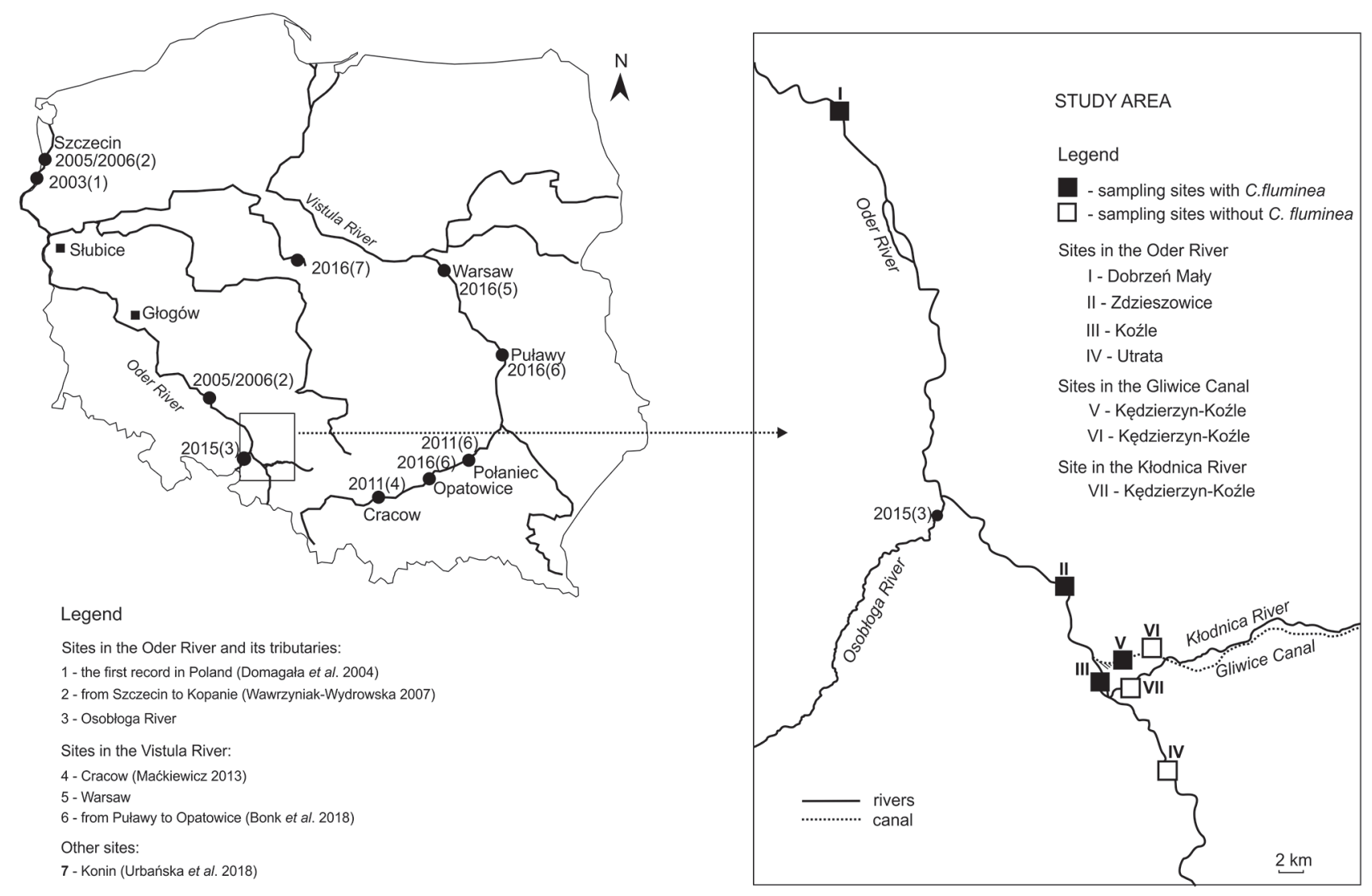

Fig. 1. Distribution of Corbicula fluminea in Poland.

other large rivers in Poland. The passive dispersal of $C$. fluminea is widely known to be predominantly attributed to human activity (deliberate or accidental), e.g., ballast water transport, use as bait, use as a food resource, releases by aquarium hobbyists, and tourist curiosity. Pediveligers or juveniles can also be dispersed in a natural way, i.e. fluvial or tidal currents or transported on mobile animals such as birds and mammals (Crespo et al., 2015; Coughlan et al., 2017). Fish also may be an alternative possibility for its passive dispersal (Gatlin et al., 2013).

In the Oder River, $C$. fluminea was detected for the first time in a heated water channel of the Lower Oder Power Station near Szczecin in 2003 (Domagała et al., 2004). Another species from this genus, i.e. Corbicula fluminalis $(\mathrm{O}$. F. Múller, 1774), was collected from this site one year later (Labęcka et al., 2005). Over the next several years, C. fluminea continued its spread in the lower and middle courses of the Oder River. It was found at six sampling sites from Zollbrücke to Ratzdorf in Germany (Müller et al., 2007) and at 14 localities on the stretch of the river from Szczecin to Kopanie in Poland (Wawrzyniak-Wydrowska, 2007). In the following years, Piechocki and Szlauer-Łukaszewska (2013) identified further records of $C$. fluminea at 11 sites in the middle course of the Oder River (on the section from Stubice to Głogów). Wilke (2007) also reported C. fluminea in the Hohensaaten-Friedrichsthal Channel, which links the end section of the Oder-Havel Canal with the Western Oder. In 2015, Asian clams were found at the mouth of the Osobłoga River, which is the left bank tributary of the Upper Oder River; however, they were mistakenly identified as Sphaerium rivicola. In 2011, live specimens of $C$. fluminea were first recorded in the Vistula River in Cracow, Poland (Maćkiewicz, 2013). It is probable that it has been present at this site since 2008 and got there due to the engineering works that were carried out in the river. In 2016, the Asian clam was collected in the Vistula River in Warsaw and, few months later, from three localities above Warsaw. Its occurrence in the Vistula River (27 findings on the stretch from Puławy to Opatowice) was also recorded in 2011-2016 (Bonk et al., 2018). The largest population and the largest individuals were noted at the outlet of a channel that collects heated water from the Połaniec Power Station as well as adjacent parts of the river (Bonk et al., 2018). In 2016, a new population of $C$. fluminea was recorded in the Warta-Gopło Channel in Konin, which is a part of a power plant lake cooling system (Central Poland) (Urbańska et al., 2018) (Fig. 1).

The expansion of $C$. fluminea has resulted in the continued increase in the number of habitats that have been colonised in the Vistula and Oder Rivers. Our study was carried out in the Upper Oder River (from Dobrzeń Mały to Utrata) in the Gliwice Canal, which links the upper course of the Oder River to the city of Gliwice in the Upper Silesian Industrial Region and in the lower course of the Kłodnica River (the right tributary of the Upper Oder River) from 2016 to 2017. Four sampling sites were situated in the Upper Oder River (along a $70 \mathrm{~km}$ stretch of the river), two in the initial stretch of the Gliwice Canal and one in the lower course of the Kłodnica River (Fig. 1). Samples of benthic macroinvertebrates were 
Table 1. Physio-chemical properties of water and type of substrates at the sampling sites.

\begin{tabular}{|c|c|c|c|c|c|c|c|}
\hline & \multicolumn{4}{|c|}{ Oder River } & \multicolumn{2}{|c|}{ Gliwice Canal } & \multirow{2}{*}{$\begin{array}{l}\text { Kłodnica } \\
\text { River } \\
\text { VII }\end{array}$} \\
\hline & $\bar{I}$ & II & III & IV & $\overline{\mathrm{V}}$ & VI & \\
\hline \multirow[t]{2}{*}{ Parameter } & $50^{\circ} 44.827^{\prime} \mathrm{N}$ & $50^{\circ} 24.708^{\prime} \mathrm{N}$ & $50^{\circ} 20.187^{\prime} \mathrm{N}$ & $50^{\circ} 16.679^{\prime} \mathrm{N}$ & $50^{\circ} 21.521^{\prime} \mathrm{N}$ & $50^{\circ} 36.318^{\prime} \mathrm{N}$ & $50^{\circ} 20.257^{\prime} \mathrm{N}$ \\
\hline & $17^{\circ} 51.396^{\prime} \mathrm{E}$ & $18^{\circ} 06.435^{\prime} \mathrm{E}$ & $18^{\circ} 09.124^{\prime} \mathrm{E}$ & $18^{\circ} 12.812^{\prime} \mathrm{E}$ & $18^{\circ} 09.615^{\prime} \mathrm{E}$ & $18^{\circ} 21.046^{\prime} \mathrm{E}$ & $18^{\circ} 10.861^{\prime} \mathrm{E}$ \\
\hline Temperature $\left({ }^{\circ} \mathrm{C}\right)$ & 12.8 & 18.3 & 19.4 & 18.1 & 24.5 & 25.4 & 21.9 \\
\hline $\begin{array}{l}\text { Oxygen } \\
\left(\mathrm{mg} \mathrm{O}_{2} \mathrm{dm}^{-3}\right)\end{array}$ & 9.10 & 5.28 & 10.9 & 9.45 & 10.41 & 4.26 & 7.78 \\
\hline Oxygenation (\%) & 85.8 & 57.8 & 92.8 & 103.3 & 128.7 & 53.2 & 91.5 \\
\hline $\mathrm{pH}$ & 7.8 & 7.4 & 8.1 & 7.8 & 7.9 & 7.5 & 7.8 \\
\hline $\begin{array}{l}\text { Alkalinity } \\
\left(\mathrm{mg} \mathrm{CaCO} \mathrm{dm}{ }^{-3}\right)\end{array}$ & 126 & 125 & 135 & 120 & 165 & 180 & 225 \\
\hline Salinity (PSU) & & 1.2 & 1.3 & 1.1 & 2.0 & 2.5 & 2.9 \\
\hline $\begin{array}{l}\text { Conductivity } \\
\left(\mu \mathrm{S} \mathrm{cm}^{-1}\right)\end{array}$ & 1581 & 2370 & 2550 & 2250 & 3800 & 4630 & 5340 \\
\hline $\begin{array}{l}\text { Chlorides } \\
\left(\mathrm{mg} \mathrm{Cl}^{-} \mathrm{dm}^{-3}\right)\end{array}$ & 333 & 490 & 468 & 481 & 1020 & 1520 & 1390 \\
\hline $\begin{array}{l}\text { Sulphates } \\
\left(\mathrm{mg} \mathrm{SO}_{4}{ }^{2-} \mathrm{dm}^{-3}\right)\end{array}$ & 112 & 134 & 114 & 97 & 296 & 380 & 412 \\
\hline $\begin{array}{l}\text { Potassium } \\
\left(\mathrm{mg} \mathrm{K} \mathrm{dm}^{-3}\right)\end{array}$ & & 8.6 & 8.6 & 7.4 & 10.4 & 18.4 & 20 \\
\hline 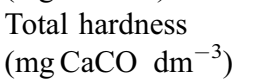 & 251 & 310 & 325 & 315 & 430 & 510 & 505 \\
\hline $\begin{array}{l}\text { Calcium } \\
\left(\mathrm{mg} \mathrm{Ca} \mathrm{dm}^{-3}\right)\end{array}$ & 67 & 80 & 75 & 73 & 98 & 112 & 120 \\
\hline $\begin{array}{l}\text { Magnesium } \\
\left(\mathrm{mg} \mathrm{Mg} \mathrm{dm}^{-3}\right)\end{array}$ & 20.5 & 26.8 & 33.5 & 32.2 & 45.0 & 56.0 & 49.9 \\
\hline $\begin{array}{l}\text { Nitrite Nitrogen } \\
\left(\mathrm{mg} \mathrm{NO}_{2}-\mathrm{N} \mathrm{dm}^{-3}\right)\end{array}$ & & 0.10 & 0.04 & 0.04 & 0.02 & 0.02 & 0.03 \\
\hline $\begin{array}{l}\text { Nitrate Nitrogen } \\
\left(\mathrm{mg} \mathrm{NO}_{3}-\mathrm{Ndm}^{-3}\right)\end{array}$ & 2.3 & 1.6 & 3.0 & 1.7 & 0.8 & 0.4 & 2.0 \\
\hline $\begin{array}{l}\text { Ammonium } \\
\text { Nitrogen } \\
\left(\mathrm{mg} \mathrm{NH}_{4}-\mathrm{N} \mathrm{dm}^{-3}\right)\end{array}$ & 0.29 & 0.54 & 0.21 & 0.37 & 0.37 & 0.36 & 0.29 \\
\hline $\begin{array}{l}\text { Phosphate } \\
\left(\mathrm{mg} \mathrm{PO}_{4}{ }^{3-} \mathrm{dm}^{-3}\right)\end{array}$ & 0.43 & 0.47 & 0.36 & 0.35 & 0.47 & 0.51 & 0.47 \\
\hline Iron $\left(\mathrm{mg} \mathrm{Fe} \mathrm{dm}^{-3}\right)$ & 0.01 & 0.34 & 0.78 & 0.63 & 0.13 & 0.32 & 0.45 \\
\hline Type of substrate & $\begin{array}{l}\text { Sandy and } \\
\text { gravel }\end{array}$ & $\begin{array}{l}\text { Sandy with } \\
\text { silt }\end{array}$ & $\begin{array}{l}\text { Sandy with } \\
\text { silt }\end{array}$ & $\begin{array}{l}\text { Sandy and } \\
\text { stones with } \\
\text { silt }\end{array}$ & $\begin{array}{l}\text { Empty shells } \\
\text { of zebra } \\
\text { mussels }\end{array}$ & $\begin{array}{l}\text { Stones } \\
\text { with silt }\end{array}$ & $\begin{array}{l}\text { Sandy and } \\
\text { stones }\end{array}$ \\
\hline
\end{tabular}

collected from the shore zone using a quadrate frame and an Ekman-Birge grab. Additionally, some physiochemical properties of the water were measured in the field and in the laboratory (Tab. 1). All of the molluscs were separated from the sediments, preserved in an $80 \%$ ethanol solution, and identified to the species level using the Piechocki and Wawrzyniak-Wydrowska key (2016). The length, height, and width of the shells of $C$. fluminea were measured using a vernier calliper. Small-sized individuals were measured using a stereoscopic microscope equipped with a camera and cellSens Standard 1.4 software.

In total, thirteen mollusc species were identified (seven gastropod species and six bivalve species). Among them, four alien species, i.e. Corbicula fluminea, Dreissena polymorpha, Physa acuta and Potamopyrgus antipodarum, were found (Tab. 2).
During our study, C. fluminea was recorded in the Oder River and in the Gliwice Canal, while it was not observed in the lower course of the Kłodnica River. In 2016, $C$. fluminea was found at two sampling sites in the Oder River, i.e. in Dobrzen Mały (the 162nd $\mathrm{km}$ of the river course) and Zdzieszowice (the 108th $\mathrm{km}$ of the river course). In 2017, it also occurred in the Oder River in Koźle (the 95th km of the river course) and at one site in the Gliwice Canal (Fig. 1). The new localities are the southernmost records of this species in the Oder River, which indicates that it is still spreading upstream.

A total of 93 individuals of $C$. fluminea were collected. Live individuals were recorded both in the Oder River (66 specimens) and in the Gliwice Canal (3 specimens). Empty shells were only found in the Oder River. The highest number 
Table 2. The checklist of molluscs collected in the studied area.

\begin{tabular}{|c|c|c|c|c|c|c|c|}
\hline & \multicolumn{4}{|c|}{ Oder River } & \multicolumn{2}{|c|}{ Gliwice Canal } & \multirow{2}{*}{$\begin{array}{l}\text { Kłodnica River } \\
\text { VII }\end{array}$} \\
\hline & $\mathrm{I}$ & II & III & IV & $\mathrm{V}$ & VI & \\
\hline Ancylus fluviatilis & - & + & + & - & - & - & - \\
\hline Bithynia tentaculata & - & + & - & + & + & + & + \\
\hline Borysthenia naticina & + & - & - & - & - & - & - \\
\hline Physa acuta* & - & + & - & - & - & - & - \\
\hline Potamopyrgus antipodarum* & + & + & + & + & + & + & + \\
\hline Radix balthica & - & + & - & - & + & + & - \\
\hline Viviparus viviparus & + & + & + & - & - & - & - \\
\hline Anodonta anatina & - & - & - & - & + & - & - \\
\hline Corbicula fluminea* & + & + & + & - & + & - & - \\
\hline Dreissena polymorpha* & + & + & + & - & + & + & + \\
\hline Pisidium sp. & - & - & + & + & - & - & - \\
\hline Sphaerium sp. & + & + & - & - & - & - & - \\
\hline Unio pictorum & - & - & + & - & - & - & - \\
\hline Number of taxa & 6 & 9 & 7 & 3 & 6 & 4 & 3 \\
\hline
\end{tabular}

+ present; - absent; * alien species.

of live individuals was recorded in the Oder River in Zdzieszowice ( 38 specimens) in 2017 . The density of the live specimens varied from 16 to 118 individuals per $\mathrm{m}^{2}$.

The shells of the $C$. fluminea that were collected were relatively small. In the Oder River, the mean dimensions of the empty shells were length $15.35 \pm 3.98 \mathrm{~mm}$, height $13.53 \pm 3.76 \mathrm{~mm}$, and width $10.13 \pm 2.67 \mathrm{~mm}$, and the mean dimensions of the live individuals were smaller, i.e. length $7.68 \pm 5.23 \mathrm{~mm}$, height $6.55 \pm 4.66 \mathrm{~mm}$ and width $4.54 \pm 3.46 \mathrm{~mm}$. In the Gliwice Canal, the mean dimensions of the shells were similar to those in the Oder River: length $8.67 \pm 3.06 \mathrm{~mm}$, height $7.50 \pm 2.94 \mathrm{~mm}$, and width $5.27 \pm 2.04 \mathrm{~mm}$. Our results show that these populations of C. fluminea consist of young individuals. This fact is typical for young, growing populations that are in the initial stage of invasion. The dimensions of the shells from the area that was studied are similar to those from other populations of $C$. fluminea in the Oder and Vistula Rivers (Domagała et al., 2004; Wawrzyniak-Wydrowska, 2007; Maćkiewicz, 2013; Bonk et al., 2018), but smaller than those from the heated Konin lakes, which most likely results from the higher water temperature in those lakes compared to the rivers (Urbańska et al., 2018).

In our study, $C$. fluminea was recorded in Dobrzeń Mały and Zdzieszowice in 2016, but one year later, individual specimens were also found in the Gliwice Canal $(8.7 \mathrm{~km}$ south of Zdzieszowice) and in the Oder River in Koźle $(10.1 \mathrm{~km}$ south of Zdzieszowice) (Fig. 1). The rate of the spread of $C$. fluminea that has been indicated by different authors varies. Schmidlin and Baur (2007) pointed out that its mean upstream spread in the Rhine River was $2.4 \mathrm{~km}$ per year via waterfowl and recreational boating. Another study that was carried out in the Rhine River in 1990 suggested that this species spreads at a much higher dispersal rate of $85-115 \mathrm{~km}$ per year (Bij de Vaate, 1991).

Our study indicates that $C$. fluminea prefers sandy-muddy sediments. It was recorded on a substrate that consisted of empty zebra mussels only in the Gliwice Canal (Tab. 1). On the other hand, Urbańska et al. (2018) noted the highest density of
C. Aluminea on a bottom that was covered with empty zebra mussel shells.

In Poland, C. fluminea is considered an alien invasive species which may endanger native species or natural habitats if it is introduced to the natural environment (the regulation of the Minister of Environmental Protection, 2011). It could post a danger especially for other bivalves by rapid growth, competition for food, earlier sexual maturity, a short life span, and high fertility (Sousa et al., 2008). Nevertheless, in small densities, it does not have to be seen as a threat for native species, but it requires monitoring as do all invasive species do (Sousa et al., 2008; Ilarri et al., 2014).

Acknowledgement. The authors are deeply indebted to the anonymous reviewers for their suggestions and comments, which improved the quality of this manuscript and to Ms. Michele L. Simmons, B.A., the University of Silesia, Katowice, Poland and Letterman Sp. z o.o., Kraków, Poland for English-language corrections, for improving the English style.

\section{References}

Bij de Vaate A. 1991. Colonization of the German part of the River Rhine by the Asiatic clam, Corbicula fluminea Müller, 1774 (Pelecypoda, Corbiculidae). Bull Zoöl Mus, Univ van Amst 13(2): $13-16$.

Bij de Vaate A, Jażdżewski K, Ketelaars HAM, Gollasch S, Van der Velde G. 2002. Geographical patterns in range extension of PontoCaspian macroinvertebrate species in Europe. Can J Fish Aquat Sci 59: 1159-1174.

Bonk M, Zając K, Lipińska AM. 2018. Rapid expansion of the Asian clam Corbicula fluminea (OF Müller, 1774): a new alien species in the mollusk community of the Vistula. Oceanol Hydrobiol Stud 47 (1): 75-86.

Coughlan NE, Stevens AL, Kelly TC, Dick JTA, Jansen MAK. 2017. Zoochorous dispersal of freshwater bivalves: an overlooked vector in biological invasions? Knowl Manag Aquat Ecosyst 418: 42. 
Crespo D, Dolbeth M, Leston S, Sousa R, Pardal MÂ. 2015. Distribution of Corbicula fluminea (Müller, 1774) in the invaded range: A geographic approach with notes on species traits variability. Biol Invasions 17(7): 2087-2101.

Domagała J, Łabęcka AM, Pilecka-Rapacz M, Migdalska B. 2004. Corbicula fluminea (O. F. Müller, 1774) (Bivalvia: Corbiculidae) a species new to the Polish malacofauna. Folia Malacol 12: 145148.

Francis RA, Chadwick MA. 2012. Invasive alien species in freshwater ecosystems: A brief overview. In: Francis RA, ed. A handbook of global freshwater invasive species. London (UK): Earthscan, pp. 3-14.

Galil BS, Nehring S, Panov V. 2008. Waterways as invasion highways-Impact of climate change and globalization. In: Biological invasions. Berlin, Heidelberg: Springer, pp. 59-74.

Gatlin MR, Shoup DE, Long JM. 2013. Invasive zebra mussels (Dreissena polymorpha) and Asian clams (Corbicula fluminea) survive gut passage of migratory fish species: Implication for dispersal. Biol Invasions 15: 1195-1200.

Gruszka P. 1999. The River Odra estuary as a gateway for alien species immigration to the Baltic Sea basin. Acta Hydrochim hydrobiol 27(5): 374-382.

Gruszka P, Woźniczka A. 2008. Dikerogammarus villosus (Sowinski, 1894) in the River Odra estuary-another invader threatening Baltic Sea coastal lagoons. Aquat Invasions 3(4): 395-403.

Gruszka P, Rokicka-Praxmajer J, Cupak J, Radziejewska T, Wolska M. 2013. Unintended "biological cargo" of ships entering the River Odra estuary: Assemblages of organisms in ballast tanks. Zesz Nauk/Akad Morska w Szczec 33(105): 22-29.

Hakenkamp CC, Palmer MA. 1999. Introduced bivalves in freshwater ecosystems: The impact of Corbicula on organic matter dynamics in a sandy stream. Oecologia 119(3): 445-451.

Ilarri MI, Souza AT, Antunes C, Guilhermino L, Sousa R. 2014. Influence of the invasive Asian clam Corbicula fluminea (Bivalvia: Corbiculidae) on estuarine epibenthic assemblages. Estuar Coast Shelf Sci 143: 12-19.

Leuven RS, van der Velde G, Baijens I, Snijders J, van der Zwart C, Lenders HR, Bij de Vaate A. 2009. The river Rhine: A global highway for dispersal of aquatic invasive species. Biol Invasions 11 (9): 1989-2008.

Lorencová E, Beran L, Horsáková V, Horsák M. 2015. Invasion of freshwater molluscs in the Czech Republic: Time course and environmental predictors. Malacologia 59(1): 105-120.

Łabęcka AM, Domagała J, Pilecka-Rapacz M. 2005. First record of Corbicula fluminalis (O. F. Müller, 1774) (Bivalvia: Corbiculidae) in Poland. Folia Malacol 13: 25-27.
Maćkiewicz JJ. 2013. The first record of the Asian clam Corbicula fluminea (Bivalvia: Veneroida: Corbiculidae) in the upper Vistula (south Poland). Folia Malacol 21(2): 87-90.

Müller O, Herpich J, Rosenberger S, Möller F, Müller N, Noske M, Jähnert K. 2007. Klimatisch begrenzte Invasion nach Osten?Aktuelles erbreitungsmuster von Corbicula fluminea in der StromOder (Brandenburg). Lauterbornia 59: 133-139.

Nentwig W, Bacher S, Kumschick S, Pyšek P, Vilà M. 2018. More than "100 worst" alien species in Europe. Biol Invasions 20: 1611-1621.

Pabis K, Krodkiewska M, Cebulska K. 2017. Alien freshwater polychaetes Hypania invalida (Grube 1860) and Laonome calida Capa 2007 in the Upper Odra River (Baltic Sea catchment area). Knowl Manag Aquat Ecosyst 418: 46.

Piechocki A, Szlauer-Łukaszewska A. 2013. Molluscs of the middle and lower Odra: The role of the river in the expansion of alien species in Poland. Folia Malacologica 21(2): 87-90.

Piechocki A, Wawrzyniak-Wydrowska B. 2016. Guide to freshwater and marine Mollusca of Poland. Poznań: Bogucki Wydawnictwo Naukowe.

Pigneur LM, Etoundi E, Aldridge DC, Marescaux J, Yasuda N, Van Doninck K. 2014. Genetic uniformity and long-distance clonal dispersal in the invasive androgenetic Corbicula clams. Mol Ecol 23(20): 5102-5116.

Schmidlin S, Baur B. 2007. Distribution and substrate preference of the invasive clam Corbicula fluminea in the river Rhine in the region of Basel (Switzerland, Germany, France). Aquat Sci 69(1): $153-161$.

Sousa R, Antunes C, Guilhermino L. 2008. Ecology of the invasive Asian clam Corbicula fluminea (Müller, 1774) in aquatic ecosystems: An overview. Ann Limnol-Int J Limnol 44(2): 85-94.

Urbańska M, Andrzejewski W, Riccardi N, Gierszal H, Golski J. 2018. The invasive Asian clam Corbicula fluminea in Polish rivers: The importance of thermal discharge from power plants for its spread. Pol J Ecol 66(1): 70-75.

Wawrzyniak-Wydrowska B. 2007. Preliminary studies on the occurrence of the Asiatic clam Corbicula fluminea (O. F. Müller, 1774) (Bivalvia: Corbiculidae) in River Odra (Poland). World Congress of Malacology, Antwerp, Belgium, pp. 238-239.

Wilke HJ. 2007. Erstnachweis von Corbicula fluminea in der Hohensaaten-Friedrichsthaler-Wasserstraße/Oder (Brandenburg). Lauterbornia 59: 63-65.

Woźniczka A, Wawrzyniak-Wydrowska B, Radziejewska T, Skrzypacz A. 2016. The quagga mussel (Dreissena rostriformis bugensis Andrusov, 1897) - another Ponto-Caspian dreissenid bivalve in the southern Baltic catchment: The first record from the Szczecin Lagoon. Oceanologia 58: 154-159. 